Egypt. Acad. J. biolog. Sci., 2 (1): 227- 236 (2009)

E.mail.egyptianacademic@yahoo.com

ISSN: $1687-8809$

Received: 20/2/2009

www.eajbs.eg.net

\title{
Combined effect of entomopathogenic nematodes and biopesticides to control the greasy cut worm, Agrotis ipsilion (Hufn.) in the strawberry fields
}

\author{
Badr EI - Sabah A. Fetoh ${ }^{1}$, Amani S. Khaled ${ }^{2}$ and Thoraia F. K. El-Nagar ${ }^{2}$ \\ 1- Plant protection Research Institute (PPRI), ARC, Dokki, Giza, Egypt. \\ 2- Department of Entomology, Faculty of Science, Ain Shams Univ., Egypt.
}

\begin{abstract}
Laboratory and field tests were conducted to evaluate the impact of the beneficial nematodes and two biopesticides when used alone or in combination against the greasy cut worm, Agrotis ipsilon (Hufn.) in infested strawberry field as a new approach of integrated pest management (IPM). Under laboratory conditions, larvae and pupae of $A$. ipsilon were highly susceptible to the two nematode species, Steinernema carpocapsal (Sc) and Heterorahabditis bacteriophora $(\mathrm{Hb})$ when used separately and the percentage mortality increase with increase the dose of nematodes. The concentration of 100 IJs was more effective than $25 \mathrm{IJs}$ for both of the two species of nematodes used. The two biopesticides: spinosad and proclaim were more effective than nematodes when used separately, spinosad was more significant effective than proclaim. Mixing of nematodes and both spinosad and proclaim increased efficacy and significance of mixtures under the laboratory and field conditions, while the effects of nematodes and biopesticides when used alone or mixed in the laboratory was higher than in the field.
\end{abstract}

Keywords: IPM, Entomopathognenic nematodes, Steinernema carpocapsae, Heterorhabditis bacteriophora, Biopesticides, spinosad, proclaim, Strawberry, Agrotis ipsilon.

\section{INTRODUCTION}

The continuous application of synthetic chemical insecticides resulted in numerous problematical situations including development of insect resistance, food hazards, ground water contamination and destruction of natural enemies. This disadvantage serves as a strong impetus for the development of alternative insect control measures. Particular attention, in recent years, has been focused on biological control agents; including certain entomopathogenic nematodes. These nematodes can be used as biological control agents to suppress a various number of economically important insect pests (Grewal et al., 2005 and Shapiro - Ilan, 2004).

Entomopathogenic nematodes in the families Steinernematidae and Heterorhabditidae are soil inhabiting insect pathogens that possess potential as biological control agents (Kaya and Gaugler, 1993) .Most biocontrol agents require days or weeks to kill their hosts, yet nematodes, working with their symbiotic bacteria, kill insects in 24 $48 \mathrm{hrs}$. The non-feeding infective juvenile stage (Ijs) seeks out insect hosts; when a host has been located, the nematode penetrates into the insect body, usually through natural body openings (mouth, anus and spiracles) or areas of thin cuticle. Nematodes kill their hosts by the aid of bacteria found in the nematode's alimentary canal. Once in the body cavity of the insect hosts, a symbiotic bacterium (Xenorhabdus for steinernematids and 
Photorhabdus for heterorhabditids) is released from the nematode, multiplies rapidly and causes rapid insect death (Adams and Nguyen, 2002 and Poinar, 1990). The nematodes feed upon the bacteria and liquefying insect; and mature into adults. Steinernematids are less pathogenic without their symbiont (Ehlers et al., 1990) and heterorhabditids are not able to kill an insect without their symbiont (Han et al., 1990).

Strawberry is one of the most popular rosaceous vegetable used as preferable fruit has a great value for local consumption and export. The greasy cut worm, Agroits ispsilon (Hufn.) is the most important pest on strawberry; larvae of all instars of the cutworm are found to be caused severe injury to strawberry plants. They are just below the surface of the ground beside the cut plants and eating of plants just above at or a short distance below the surface of the soil. Following their usual habit of injuring succulent stems. These caterpillars often cut off the petioles of the leaves of strawberry plants or the stems of the young fruits, also attack the green and full grown fruits from below, often hollowing it out leaving the shell of the berry. (Taha, 1984).

Spinosad is a fermentation product produced by one or more chemical mutants of naturally occurring actinomycetes soil bacterium Saccharopolyspora spinosa (Boek et al., 1994). Spinosad has been applied to over 200 different crops. Spinosad was described by (Sparks et al., 1996) as fermentation-derived molecules that contain a 12-membered macrocyclic lactone in a unique tetracyclic ring. Spinosad combines the best features of synthetic chemical insecticides and naturally derived biological insect control products. It has the efficacy, broad-spectrum activity against lepidopterous pests e.g. Ostrinia nubilalis, Helicoverpa zea, Trichoplusia ni, Plutella xylostella, Spodoptera spp., Heliothis spp and Pieris rapae. Also used for urban pest control e.g. Agrotis ipsilon. It is effective as bait for fruit flies Ceratitis spp. and Bactrocera spp. and some sucking lice and ants (Thompson et al., 2000). Spinosad also has a very favorable safety profile towards mammals (Sparks et al., 1995), reduced environmental risk and phytotoxicity (Harris and Maclean, 1999) and safety to beneficial insects (Schoonover and Larson, 1995 and Sparks et al., 1995). In fact, the low toxicity of spinosad toward beneficial allows it to be incorporated into most (IPM) programs that heavily rely on predators and parasites (Bret et al., 1997). Proclaim is a highly potent pesticide unique foliar insecticide that control lepidopteron pests (caterpillars and worm) in Cole crops, turnip greens in addition to leafy and fruiting vegetables. Proclaim effectively controls the larvae stages of many pests at low rates and increasing the crop's value.

Proclaim contains the active ingredient emamectin benzoate, a semi - synthetic second generation a vermectin pesticides. Avermectins are gained from a naturally occurring soil bacterium Streptomyces avermitilis. Proclaim can be applied by ground air or ground only, giving the growers the flexibility needed for effective integrated pest management (IPM) programs. (Jansson et al., 1997). The present work was carried out to study the integration between the entomopathogenic nematodes and biopesticides when used alone or mixed on the greasy cut worm, Agrotis ipsilon (Hufn.) under laboratory and field conditions.

\section{MATERIALS AND METHODS}

\section{Laboratory bioassays:}

Infective third stage juveniles (IJs) of one Steinernematid nematode Steinernema 
carpocapae ( $\mathrm{Sc}$ ) and one Heterorhabdit nematode Heterorhabditis bacteriphora $(\mathrm{Hb})$ were used in this study. They were cultured on the last instar larvae of the wax moth, Galleria mellonella Dutky et al., (1964) under laboratory conditions. Larval instars and pupae of A. ipsilon were collected from infested field. The main goal of this bioassay was to study the efficiency of nematodes and biopesticides (spinosad "S" and proclaim "P") on the larval and pupal stages. The tested nematodes were suspended in distilled water to obtain the desired concentrations. Three concentrations of the nematodes $\mathrm{Sc}$ and $\mathrm{Hb} 25$, 50 and $100 \mathrm{IJs} / \mathrm{ml}$ were tested. Twenty five individuals of $4^{\text {th }}$ larval instars and 2 days old pupae of A. ipsilon were treated in Petri dishes (one larva or pupa / dish furnished with filter paper, sprayed with $1 \mathrm{ml}$ of different concentrations of a nematode suspension above it some strawberry leaves). This procedure is according to Fetoh and Azazy (2004). Three replicates for each larval and pupal stage were performed for each tested concentrations. Mortality of the larvae and pupa were calculated after 48 hours. Groups of 10 dead larvae and pupae from each concentration were transferred to extracting dishes on white traps to collect nematodes existing from infested cut worm instars and this procedure carried out under laboratory conditions of $25 \square 2^{\circ} \mathrm{C}$ and $65 \square 2 \%$ R.H. Larval and pupal mortality were recorded daily and nematode development in cadavers of cut worm was ensured after seven days.

\section{Biopesticides:}

The two biopesticides spinosad and proclaim (5\% E.C.) were tested in the present study. The same technique was repeated with the biopesticides with slight modification that strawberry leaves previously dipped at the desired concentration of $0.125 \mathrm{mg} / \mathrm{L}$, for each other, recommended dose according to Agriculture Ministry (2007) and experiment replicated also three times.

\section{Field application:}

Field trials were carried out in strawberry field at El-kassasen region, Ismailia governorate during February, 2009, cultivated area was one feddan $\left(1\right.$ feddan $\left.=4200 \mathrm{~m}^{2}\right)$ using portable sprayer, two liters capacity. The spray was directed towards the ground around the stems of the strawberry plants in early morning. A. ipsilon larvae and pupae counts were taken from random samples of 50 plants (5 replicates x 10 plants) before spraying and 7 days after spraying with 2 liters of each nematode suspension (2000 $\mathrm{IJ} / \mathrm{ml}$ ) for each Sc and $\mathrm{Hb}$, respectively, according to Fetoh and Azazy, (2004) and with $0.125 \mathrm{mg} / \mathrm{L}$. for spinosad and proclaim, separately or mixture from $\mathrm{Sc}+$ spinosad and $\mathrm{Sc}$ + proclaim) and mixture of $(\mathrm{Hb}+$ spinosad and $\mathrm{Hb}+$ proclaim). Control was treated with water only. Samples were taken from control and treated plots were counted before applications and one week after application. The percentage of reduction in A. ipsilon population in relation to the sprayed nematodes, spinosad and proclaim suspensions were calculated according to Henderson and Tiliton equation (1955).

\section{Statistical analysis:}

The data presented in percentage values in this offered study were normalized using arcsine transformation. The significance of the main effects was determined by analysis of variance (ANOVA). The significance of various treatments was evaluated by Duncan's multiple range test $(\mathrm{P}<0.05)$ SAS Institute, (1988). 


\section{RESULTS AND DISCUSSION}

\section{1- Laboratory bioassay:}

\section{a. Susceptibility of $\boldsymbol{A}$. ipsilon to entomopathogenic nematodes:}

The obtained results in Table (1) show that mean mortality by the EPN (Sc) and $(\mathrm{Hb})$ have no significant difference among all the treatments $(\mathrm{P}<0.05)$ although they numerically differences ranging from $(70-100 \%)$ and $(50-100 \%)$ for larvae and pupae treated with Sc nematode, respectively, and ranging from (80-100\%) and (70-100\%) for larvae and pupae treated with $\mathrm{Hb}$ nematode, respectively (Figs. 1 and 2). A positive relation was evident between percent mortality and nematode concentration. In other words, mortality was concentration dependant. Laboratory bioassay proved that the entomopathogenic nematodes (EPN) were highly virulent to A. ipsilon, the virulence of nematodes species differed greatly among associated symbiosis bacteria Dunphy and Webster, (1988). Generally there are no significant differences among the tested concentrations (25, 50 and $100 \mathrm{IJs})$ on larvae and pupae. Hussein (2004) found that the Egyptian nematodes were as efficient as the imported ones and in some cases had higher efficacy in controlling S. littoralis and A. ipsilon. The pupae of the cutworm were less susceptible to nematode infections than larvae because of the reduced number of portal entry Kaya, (1984), Azazy, (2001) and El-Kholy (2004). Ghally et al., (1992) found that pupae of Musca domestica were refractory to nematode infection, presumably owing to the effective protection afforded by the puparium.

Table (1): Susceptibility of $4^{\text {th }}$ instar larvae and 2 day old pupae of A. ipsilon to different concentration of $\mathrm{Sc}$ and $\mathrm{Hb}$ nematodes.

\begin{tabular}{||c||c||c|c||c||}
\hline \multirow{2}{*}{$\begin{array}{c}\text { Nematodes } \\
\text { Concentration } \\
(\mathrm{Ijs} / \mathrm{ml})\end{array}$} & \multicolumn{4}{|c||}{ Mean \% mortality } \\
\cline { 2 - 5 } & \multicolumn{2}{|c|}{ Larvae } & \multicolumn{2}{c||}{ Pupae } \\
\cline { 2 - 5 } & $\mathrm{Sc}$ & $\mathrm{Hb}$ & $\mathrm{Sc}$ & $\mathrm{Hb}$ \\
\hline \hline 25 & $70 \pm 14.7$ & $80 \pm 4.0$ & $50 \pm 5.7$ & $70 \pm 6.5$ \\
& $(52-88)$ & $(75-85)$ & $(42-55)$ & $(62-78)$ \\
\hline \hline 50 & $85 \pm 4.0$ & $90 \pm 3.6$ & $70 \pm 3.7$ & $85 \pm 2.5$ \\
& $(80-90)$ & $(87-95)$ & $(66-77)$ & $(82-88)$ \\
\hline \hline 100 & $100 \pm 0.0$ & $100 \pm 0.0$ & $100 \pm 0.0$ & $100 \pm 0.0$ \\
& $(100-100)$ & $(100-100)$ & $(100-100)$ & $(100-100)$ \\
\hline
\end{tabular}

Number between the brackets refers to the range of mortality in the replicates $(\mathrm{Sc})$ Steinernema carpocapsal $(\mathrm{Hb})$ Heterorahabditis bacteriophora (Ijs) Infective third stage juveniles.

Fig. (1): Effect of different concentrations of entomopathogenic nematodes on larvae of A. ipslion.

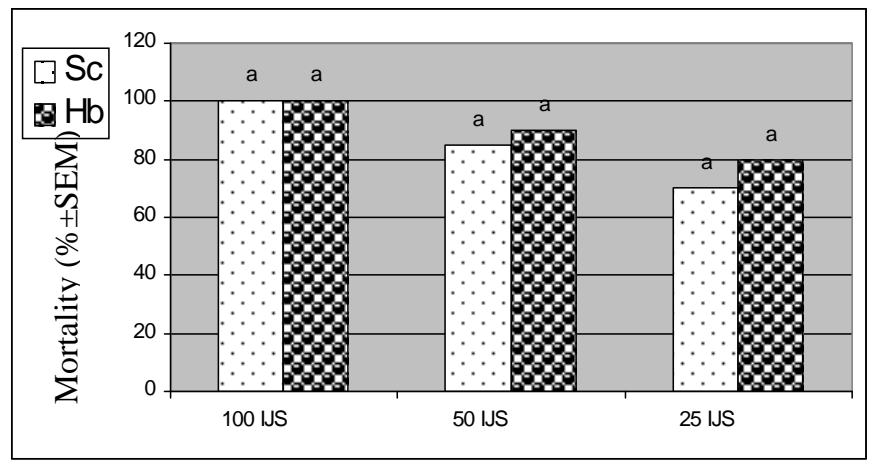

nematodes concentrations $(\mathrm{Ijs} / \mathrm{ml})$

Means with the same letters are non significant different $(\mathrm{P}<0.05)$. 
Fig. (2): Effect of different concentrations of entomopathogenic nematodes on pupae of $A$. ipslion.

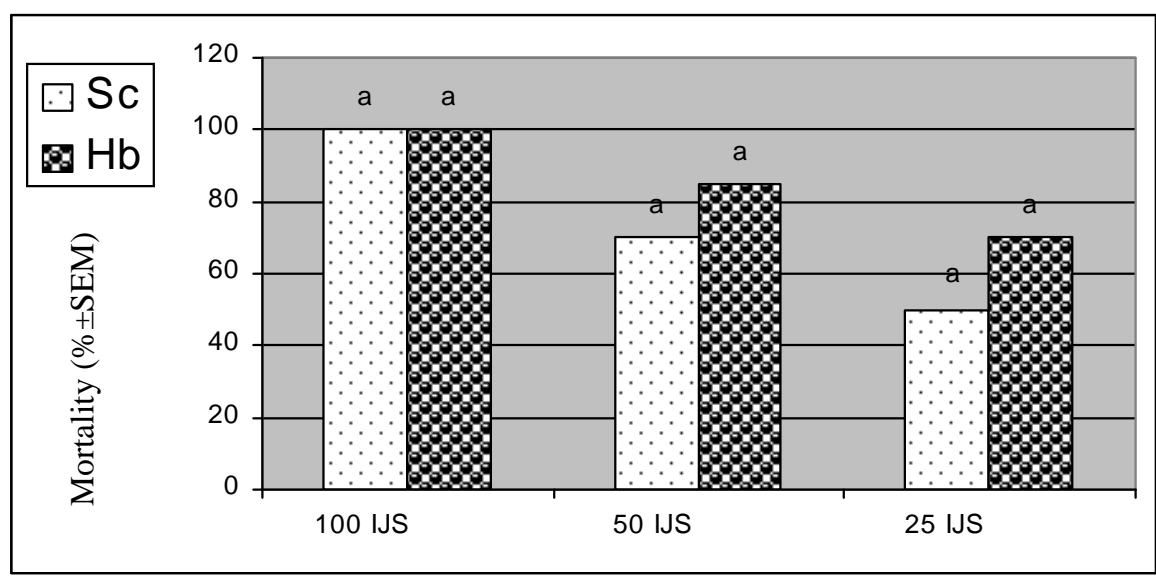

nematodes concentrations ( $\mathrm{Ijs} / \mathrm{ml})$

Means with the same letters are non significant different $(\mathrm{P}<0.05)$.

(Sc) Steinernema carpocapsal $(\mathrm{Hb})$ Heterorahabditis bacteriophora

\section{b. Susceptibility of $\boldsymbol{A}$. ipsilon to the two biopesticides:}

Data concerning with the effect of the recommended dose $0.125 \mathrm{mg} / \mathrm{L}$ of both tested biopesticides on the $4^{\text {th }}$ instar larvae of $A$. ipsilon illustrated in Fig.(3). The percentage of dead larvae were 99 and $89 \%$ for spinosad and proclaim, respectively. Spinosad was high effective more than proclaim because its effect work on neural system while proclaim work with digestive system. Hill and Foster, (2003). Wanner et al., (2000) reported that paralysis was the primary effect of spinosad, with mortality as a secondary result. Also, this percentage mortality may reflect that the two biopesticides were of toxic action higher than that of the nematodes alone.

Fig. (3): Effect of nematodes and the two biopesticides alone or mixtures of nematodes and biopesticides on larvae of $A$. ipslion under laboratory conditions.

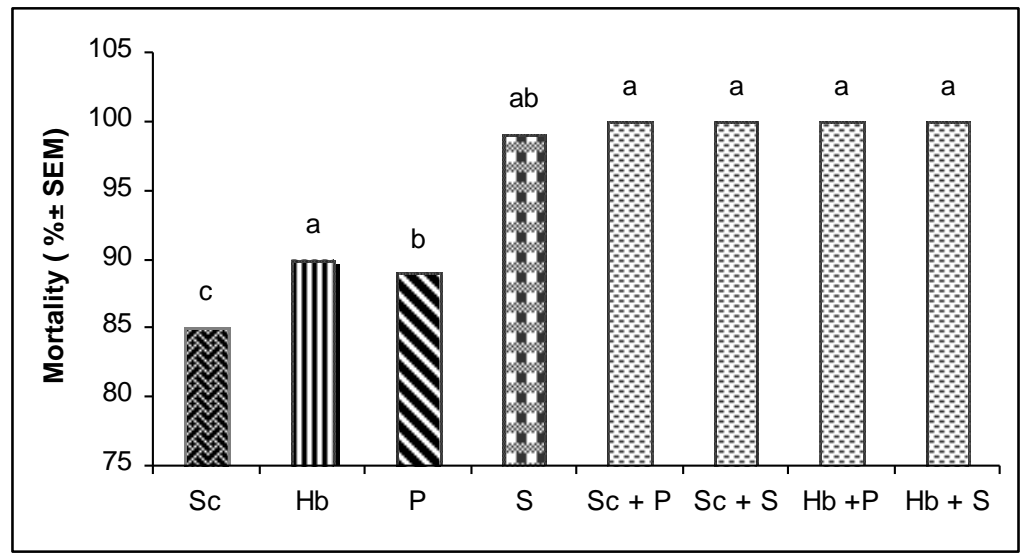

Means with the same letters are non significant different $(\mathrm{P}<0.05)$. 


\section{c. Susceptibility of $A$. ipsilon to mixture of nematodes and the two biopesticides. 1- In the laboratory:}

Percentage mortality among $4^{\text {th }}$ instar larvae of $A$. ipsilon due to the combined application of $\mathrm{Sc}$ and $\mathrm{Hb}$ nematodes and the two biopesticides at concentration (50Ijs + $0.125 \mathrm{mg} / \mathrm{L}$ ) were $100 \%$ for all application (Fig. 3). It showed an apparent increase in efficacy of the nematodes on the combination treatment.

The obtained data also reveal that there were high significant differences between the effect of the two nematodes alone at the same concentrations and the effect of nematodes + spinosad and nematodes + proclaim.

The present results are in agreement with Fetoh and Azzazy (2004).

\section{2- In the Field:}

Percentage mortality of A. ipsilon due to application of $\mathrm{Sc}, \mathrm{Hb}$ spinosad and proclaim alone or in combined are shown in (Fig. 4). The obtained data reveal that there was significant difference of mortality between $\mathrm{Sc}$ and $\mathrm{Hb}$ nematodes, where $\mathrm{Hb}$ nematode had more insecticidal action than SC nematode. But there were significant differences of mortality between all treatments and Sc nematode application alone. The obtained data also reveal that the mixture of Sc nematode and spinosad and proclaim increased the mortality significantly than utilization of Sc alone. The percentage mortality of Sc alone was $70 \%$ and with combined of spinosad and proclaim were 83 and $75 \%$, respectively, indicating a considerable improvement in the efficacy of Sc nematode applied in combination with the two biopesticides over that of nematode alone. In case of $\mathrm{Hb}$ nematode percentage mortality increased significantly when combined with spinosad (92\%), on the other hand, the percentage mortality due to the combined application of $\mathrm{Hb}$ and proclaim, remained without change $(80 \%)$. It was also noticed that the combined application showed no effect in this treatment. Koppenhoffer and Kaya, (1997) and Koppenhoffer et al., (1999) reported that some pesticides act synergistically or additively with Entomopathogenic nematodes and therefore improve nematodes efficacy in inundative applications such as B. thuringiensis.

Fig. (4): Effect of nematodes and the two biopesticides alone or mixtures of nematodes and biopesticides on larvae of $A$. ipslion under filed conditions.

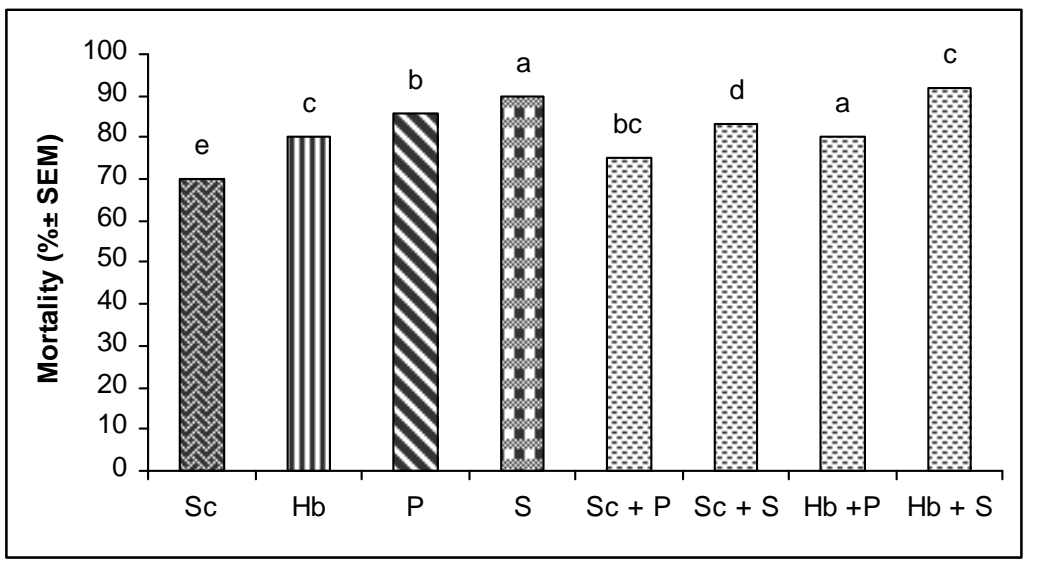

Means with the same letters are non significant different $(\mathrm{P}<0.05)$. Sc: Steinernema carpocapsal Hb: Heterorahabditis bacteriophora S: spinosad P: proclaim 
The results also indicated that spinosad was the faster killer of $A$. ipsilon followed by proclaim, while EPN came next with regard to host morality. Spinosad acts quickly and had speed of kill comparable to most synthetic insecticides. This is largely due to its contact mode of entry (Salgado, 1998). Moreover, he also proved that spinosad has the combination of contact and ingestion activity. Meanwhile, the proclaim also has some contact activity but the larvae should ingest it Hill and Foster, (2003).

Generally it could be concluded that larvae of A. ipsilon in the field less susceptible to the effect of the nematodes and biopesticides than in the laboratory. Woodring and Kaya, (1988), reported that infectivity of steinernematids and heterorhabditids nematodes varied greatly due to some environmental factors or requirements. These environmental requirements could be physical or biotic parameters.

Finally, the trails demonstrate those biological control agents such as entomopathogenic nematodes and the biopesticides spinosad and proclaim may help in controlling of A. ipsilon under field conditions. This finding is in agreement with Fetoh and Azzazy (2004).

\section{REFERENCES}

Adams, B. J. and Nguyen, K. B. (2002). Taxonomy and systematic. In: Gauglar, R. (Ed.), Entomopathogenic Nematology. CABI, New York, NY, 1-34.

Agriculture Ministry (2007). Technical Recommendation of Controlling Agriculture Pests. pp: 238-240.

Azazy, A. M. (2001). Comparative studies between insect pathogenic nematodes and other nematodes in controlling some soil insect and fruit tree borers. Ph.D. Thesis, Fac. Mohstohor Agric. Zagazig, Univ. 200 p.

Boek, L. D.; C. Hang, T. E. Eaton, O. W. Godfrey; K. H. Michel, W. M. Nakatsukasa and R. C. Yao. (1994). Process for producing A 83543 compounds. US Patent No. 5:362- 624 .

Bret, B. L.; Larson, L. L.; Schoonover, J. R.; Sparks, T. C. and Thompson, G. D. (1997). Biological properties of Spinosad. Down to Earth 52: 6-13.

Dunphy, G. B. and J. M. Webster. (1988). Virulence mechanism of Heterorhabdits heliothidis and its bacterial associate in non- immune larvae of the greater wax moth, Galleria mellonella. International J. Parasitology. 18 (6): 729 - 737.

Dutky, S. R., Thompson, J. V. and Cantwell, G. E. (1964). A technique for the mass propagation of the DD-136 nematode. J. Insect. Pathol, 6: 417- 422.

Ehlers, R-U; Stoessel, S. and Wyss, U. (1990). The influence of phase variants of Xenorhadus spp. and Escherichia coli (Enterobacteriaceae) on the Heterorhabditis. Revue Nematol., 13: 417- 424.

El-Kholy, M. Y. M. (2004). Utilization of entomopathogenic nematodes and bacteria in controlling Cabbage pests. Ph.D. thesis Fac. Sci. Ain Shams Univ., Egypt.

Fetoh, Badr El- Sabah, A. And Azzay, A. M. (2004). Integration of three biocontrol agents for the control of the cabbage worm, Pieris rapae. Egypt. J. Biolo. Pest Control, 14(1): 225-230.

Ghally, S. E.; Kamel, E. G. and Naser, N. M. (1992). Comparative studies on the production of invasive larvae of Steinernema feltiae Filipjev nematodes within 
insect host. J. Egypt. Society of Parasitology, 22 (3): 683-692.

Grewal, P., Ehlers, R. U. and Shapiro - Ilan, D (Ed.), (2005). Nematodes as Biological control Agents. CABI publishing, Walling ford. UK.

Han, R. C.; Wouts, W. M. and Li, L.Y. (1990). Development of Heterorhabditis spp. strains as characteristics of possible Xenorhabdus luminescens subspecies. Revue Nematol., 13: 411-415.

Harris, B. M. and Maclean, B. (1999). Spinosad; control of lepidopteeraous pests in vegetable brassiscas. Proceedings of the $52^{\text {nd }}$ Plant protection conf. 65-69.

Henderson, C. F. and Tilton, W. (1955). Tests with Acaricides against the brown wheat mite. J. Econ. Ent., 48 (2): 157 - 161.

Hill, T. A. and Foster, R. E. ( 2003). Influence of selected insecticides on the population dynamics of diamondback moth (Lepidopter: Plutellidae) and its parasitoid Diadegma insularae in cabbage. J. Ent. Sci. 38: 59 - 71.

Hussein, Mona A. (2004). Utilization of Entomopathogenic nematodes for biological control of some Lepidopterous pests. Ph.D. thesis Fac. Sci. Ain Shams Univ., $203 \mathrm{pp}$

Jansson, R K., R. F. Peterson, P. K. Mooke, Jee, W. R. Halliday and R. A. Dybas. (1997). Development of novel soluble granule formulation of enamectin benzoate for control of lepidopterous pest. Florida Entomologists, 80: 425 - 450.

Kaya, H. K. (1984). Effect of the entomopathogenic nematode Naplectana carpcapose on the tachinid parasite Compsieler concinnata (Diptera: Tachinidae). J. Nematology. 16:9-13.

Kaya, H.K.; and Gaugler, R. (1993). Entomopathogenic nematodes. Ann. Rev. Entomol., 38: 181-206

Koppenhoffer, A. M. and Kaya, H. K. (1997). Additive synergistic interaction between entomopathogenic nematodes and B. thuringiensis for scarab grul control. Biological Control. 8:131-137.

Koppenhoffer, A. M.; Choo, H. Y.; Kaya, H. K.; Lee, D. W. and Gelernter, W. D. (1999). Increased field and green house efficacy against scarab grubs with a combination of an Entomopathogenic nematode and B. thuringiensis. Biological Control. 14: $37-44$.

Poinar, Jr., G. O. (1990). Biology and Taxonomy of Steinernematide and Heterorhabditidae. In: Gaugler, R. and Kaya, H. K. (Ed.), Entomopathogenic Nematodes in Biological control. CRC Press, Boca Raton, FL: 23-62.

SAS Institute. (1988). "SAS" User's Guide statistics. SAS Inst., Cary, Nc.

Salgado, V. L. (1998). Studies on the mode of action of spinosad: symptoms and physiological correlates. Pest. Bio-chem. Physiol. 60: 91-102.

Schoonover, J. R. and Larson, L. L. (1995). Laboratory activity of spinosad on non target beneficial arthropods. Arthropod Mang., 20: 357.

Shapiro-Ilan, D. I. (2004). Entomopathogenic nematodes and insect management. In: Capinera, J. L. (Ed.), Encyclopedia of Entomology. Vol. 1 Kluwer Academic publishing Dordrecht, The Netherlands: $781-784$.

Sparks, T. C.; Thompson, G. D.; Larson, L. L.; Kirst, H. A.; Jantz, O. K.; Worden, T. V.; Hertlien, M. B. and Busacca, J. D. (1995). Biological characteristic of the spinosyns: new naturally derived insect control agents. In proceedings, Beltwide Cotton Conf.s, National cotton council, Meinphis. TN. PP. 903-907. 
Sparks, T. C.; Kirst, H. A.; Mynderse, J. S.; Thompson, G. D.; Turner, J. R.; Jantz, O. K..; Hertlein, M. B.; Larson, L. L.; Baker, P. J.; Broughton, M. C.; Busacca, J. D.; Creemer, L. C.; Huber, M. L.; Martin, J. W.; Nakatsukasa, W. M.; Paschal, J. W. and Worden, T. V. (1996). Chemistry and biology of the spinosyns: components of spinosad (Tracer), the first entry into DowElanco,s naturalyte class of insect control products. 1996 Proceedings, Beltwide Cotton Conf.s, Nashville, TN, USA, January 9-12. 2: 692-695.

Taha, A. M. (1984). Studies on some pests infesting strawberry plants at Qalubia governorate. M. Sc. Fac. Agric. Al-Azhar univ., 146 P.

Thompson, G. D.; Dutton, R. and Sparks, T.C. (2000). Spinosad a case study: an example from a natural products discovery program. Pest Management Sci. 56: 696-702.

Wanner, K. W.; Helson, B. V. And Harris, B. J. (2000). Laboratory and field evaluation of spinosad against the gypsy moth, Lymontria dispar. Pest. Mang. Sci., 56: 855-860.

Woodring, J. L. and Kaya, H. K. (1988). Steinernematid and Heterorhabditid nematodes: A handbook of echniques. Arkansas agricultural Experiment Station Southern Cooperative Bulletin 331, 30 p. 


\section{ARABIC SUMMARY}

Agrotis التكامل بين النيماتودا الممرضة للحشرات والمبيدات الحيوية لمكافحة الدودة القارضة ipsilon

$$
\begin{aligned}
& 1 \text { أماني سليمان خالدوثريا فهيم قطب النجار2 } 2
\end{aligned}
$$

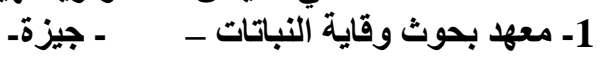

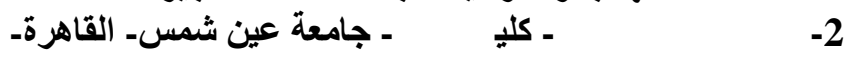

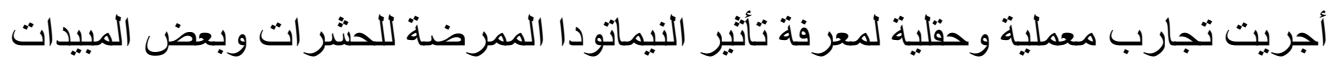

الحيوية منفردة ومخلوطة علي الدودة القارضة Agrotis ipsilon في حقول فراولة مصابة بها

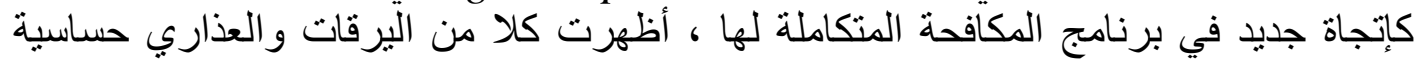

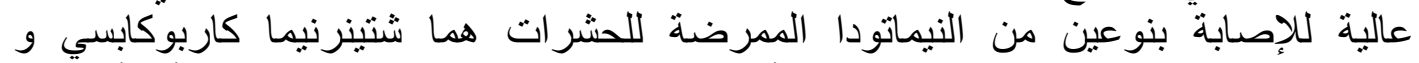
هيتيرور اهيبديتيس باكثروفورا ، وقد كان تأثير التركيزات المختلفة منهما تصاعديا أي أنه كلما زاد التركيز زادت نسب الموت، وكانت المبيدات الحيوية المستخدمة مثل الاسبينوساد و البروكلام أكثر فاعلية من النيماتودا عند إستخدامهيا منفردين ، وقد كان الاسبينوساد أكثر فعالية من البروكلام ، وعند خلط النيماتودا مع كل من الاسبينوساد و البروكلام كلا علي حدة وكان

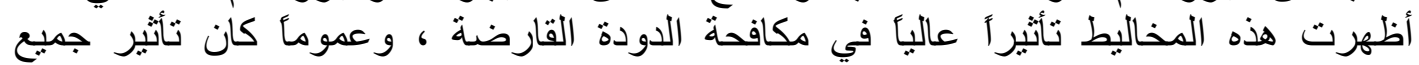
المعاملات في المعمل أكثر تأثيرًا عنه في الحقل، وإن كانت جميع المعاملات لها تأثنير فعال في الحقل مما يشجع علي إستخدامها في بر امج المكافحة المتكاملة. 